\title{
Synthesis of High Specific Surface Lithium ion Sieve Templated by Bacterial Cellulose for Selective Adsorption of $\mathrm{Li+}$
}

Xudong Zheng ( $\square$ Zhengks@outlook.com)

Changzhou University https://orcid.org/0000-0003-2688-4855

\section{Ang Li}

Changzhou University

\section{Dandan Wang}

Changzhou University

\section{Da Xia}

Changzhou University

Yuzhe Zhang

Changzhou University

\section{Zhongyu Li}

Changzhou University

\section{Research Article}

Keywords: Lithium ion sieve, Bacterial cellulose, Hydrothermal method, Titanium, Selective adsorption

Posted Date: June 21st, 2021

DOI: https://doi.org/10.21203/rs.3.rs-580568/v1

License: (9) (i) This work is licensed under a Creative Commons Attribution 4.0 International License. Read Full License 


\section{ipSynthesis of high specific surface lithium ion sieve templated by}

\section{bacterial cellulose for selective adsorption of $\mathbf{L i}^{+}$}

Xudong Zheng*, Ang Li, Dandan Wang, Da Xia, Yuzhe Zhang, Zhongyu Li ${ }^{*}$

*Correspondence to: X. Zheng (E-mail: zhengks@outlook.com); Z. Li (E-mail: zhongyuli@mail.tsinghua.edu.cn);

\section{Graphical Abstract}

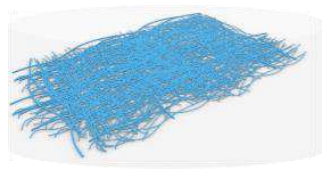

BC
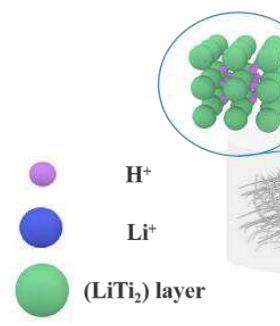

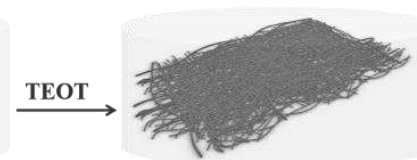

$\mathrm{TiO}_{2} / \mathrm{BC}$

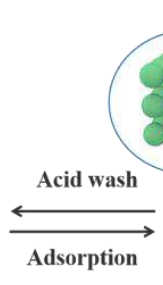

$\mathrm{H}_{2} \mathrm{TiO}_{3}$

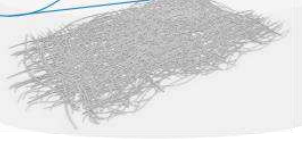

Lithium ion sieve templated by bacterial cellulose for selective adsorption of $\mathrm{Li}^{+}$

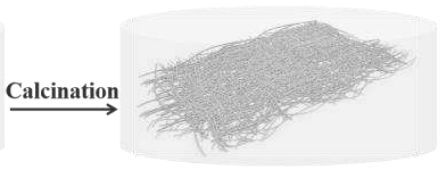

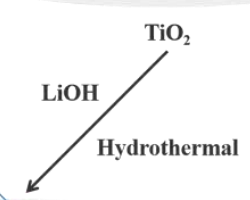
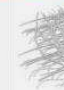

$$
\mathrm{Li}_{2} \mathrm{TiO}_{3}
$$

\section{Abstract}

In recent years, the lithium market has ushered in a golden period of development. With the development of batteries, ceramics, glass, lubricants, refrigerants, the nuclear industry and the optoelectronics industry, the demand for lithium has grown rapidly, and continuous mining has led to scarcity of land resources. On the other hand, due to the rich lithium resources in sea water and salt lake brines. How to selectively adsorb and separate lithium ions from seawater and salt lake brine has attracted more and more scholars' attention and research. Lithium ion sieve stands out because of its excellent performance of specific adsorption and separation of lithium ions. This article reports the preparation of mesoporous $\mathrm{TiO}_{2}$ and $\mathrm{LiOH}$ hydrothermal reaction using bacterial cellulose as a biological template. After calcination at $600^{\circ} \mathrm{C}$, spinel lithium titanium oxide $\mathrm{Li}_{2} \mathrm{TiO}_{3}$ is formed. $\mathrm{H}_{2} \mathrm{TiO}_{3}$ was obtained by eluting the precursor with $\mathrm{HCl}$ eluent. FT-IR, SEM and XRD were used to characterize $\mathrm{Li}_{2} \mathrm{TiO}_{3}$ and $\mathrm{H}_{2} \mathrm{TiO}_{3}$. The adsorption performance of $\mathrm{H}_{2} \mathrm{TiO}_{3}$ was 
studied through adsorption $\mathrm{pH}$, adsorption kinetics, adsorption isotherms, competitive adsorption and so on. The results show that $\mathrm{H}_{2} \mathrm{TiO}_{3}$ is a single layer chemical adsorption process, which has a good adsorption effect on lithium ions at $\mathrm{pH}$ 11.0, with the maximum adsorption capacity can reach $35.45 \mathrm{mg} \cdot \mathrm{g}^{-1}$. The lithium ion sieve has selective adsorption to $\mathrm{Li}^{+}$, and its distribution coefficient is $2242.548 \mathrm{~mL} \mathrm{~g}^{-1}$. It may be predicted that the lithium-ion sieve prepared by biological template has a broad application prospect.

Keywords: Lithium ion sieve; Bacterial cellulose; Hydrothermal method; Titanium; Selective adsorption

\section{Introduction}

Lithium is the rarest element among alkali metals(Zeng et al. 2018). It is the lightest silver-white metal with strong chemical activity, can synthesize inorganic and organic compounds of lithium with various elements. Lithium and a variety of metals constitute light alloys, wear-resistant alloys, etc. Al-Li and $\mathrm{Mg}-\mathrm{Li}$ alloys will become new structural materials for the next generation of aerospace industry. Lithium resources in China are mainly distributed in Qinghai-Tibet Plateau, Xinjiang, Inner Mongolia, Sichuan and Jiangxi, accounting for $25.6 \%$ of the world's lithium reserves, ranking second in the world(DING et al. 2018). Among them, salt lake brine lithium resources are the main form of lithium resources in China, accounting for about $85 \%$ of the total proved lithium reserves in China(Liu et al. 2021). Therefore, it is very important to study how to transform lithium extraction technology and extract lithium efficiently from Salt Lake brine(Argurio et al. 2019). At present, there are many known methods for adsorption and separation of lithium $\mathrm{Li}^{+}$from salt lake brine. For example, precipitation method(Song et al. 2017), electrochemical method(Romero et al. 2018), solvent extraction method(Gza et al. 2020; Zhao et al. 2017), ion exchange method(Grágeda et al. 2018; Michel et al. 2018) and so on. Among them, ionexchange method stands out from many lithium extraction methods because of its simple process, high recovery rate and economic and green advantages(Ma et al. 2018). Compared with some natural inorganic minerals and carbon materials(Wen et al. 2017), there is a lack of adsorption selectivity(Lihua et al. 2018) for $\mathrm{Li}^{+}$. Lithium 
ion sieve has the characteristics of selective adsorption of $\mathrm{Li}^{+}$because it is first inserted into the precursor by $\mathrm{Li}^{+}$and then eluted by eluent(Peng et al. 2019). As the main representative of lithium ion sieves, spinel manganese oxide ion sieves have high specific adsorption for $\mathrm{Li}^{+}$after acid elution of precursors. For example, Gao A, Sun $\mathrm{Z}$ and others synthesized representative adsorbent $\mathrm{Li}_{1.6} \mathrm{Mn}_{1.6} \mathrm{O}_{4}$ for lithium ion sieves(Gao et al. 2018). Its maximum adsorption capacity can reach $44 \mathrm{mg} \cdot \mathrm{g}^{-1}$. Similarly, Yang, Shan Shan, Zhou, Ma Li, Ma Li et al. Through LiOH, $\mathrm{Mn}\left(\mathrm{CH}_{3} \mathrm{COO}\right)_{2}, \mathrm{H}_{2} \mathrm{O}_{2}$ and ethanol, using sol gel method, hydrothermal method and low-temperature solid-phase method combined with manganese oxide lithium ion sieve made a series of research(Yang et al. 2016). Keiko Sasaki and Qianqian Yu and their colleagues synthesized a lithium ion sieve with microtubule morphology using manganese-oxidizing fungus as biological template by calcination solid-phase bonding. The effect of adsorption capacity at different calcination temperatures was studied. The structural and morphological characterization and adsorption experiments show that the weight fraction of spinel lithium manganese oxide ion sieve also changes with different calcination temperatures, and it will affect its crystallinity, so the choice of calcination temperature directly affects the adsorption capacity of lithium ion sieve(Sasaki and Yu 2015). Song et al. Spinel structure $\mathrm{Li}_{1+\mathrm{x}}$ $\mathrm{Mn}_{2-\mathrm{x}} \mathrm{O}_{4}$ materials for lithium ion-sieve precursor were synthesized by high temperature solid state method. The results showed that the $\mathrm{Li}_{1.3} \mathrm{Mn}_{1.7} \mathrm{O}_{4}$ material had the largest adsorption capacity and it reached up to $24.06 \mathrm{mg} \cdot \mathrm{g}^{-1}$ when the $\mathrm{pH}$ value was 12 and the adsorption time was $10 \mathrm{~h}$ (Img et al. 2021). However, the current LiMn-O ion sieve have the same shortcomings in the process of acid pickling: the appearance of $\mathrm{Mn}^{2+}$ in the process of elution causes partial dissolution of the ion sieves, which reduces the repeatability of the lithium ion sieves. On the other hand, the appearance of titanium-based lithium ion sieves compensated for the dissolution of Ti during acid pickling. For example, Shulei Wang, Ping Li and others synthesized $\beta-\mathrm{Li}_{2} \mathrm{TiO}_{3}$ by hydrothermal method of $\mathrm{TiO}_{2}$ and $\mathrm{LiOH} \cdot \mathrm{H}_{2} \mathrm{O}(\mathrm{Zhang}$ et al. 2019). Compared with manganese ion sieves, the dissolution rate of $\mathrm{Ti}$ is also reduced while $\mathrm{Li}^{+}$is highly selectively adsorbed by manganese ion sieves. Cheng-Long Yua, 
Kazumichi Yanagisawa et al, synthesized pure $\mathrm{Li}_{2} \mathrm{TiO}_{3}$ nanoparticles by hydrothermal reaction of anatase $\mathrm{TiO}_{2}$ and $\mathrm{LiOH} \cdot \mathrm{H}_{2} \mathrm{O}$, and studied the formation of $\mathrm{Li}_{2} \mathrm{TiO}_{3}$, the diffusion and insertion mechanism of lithium ions(Garay-Rodríguez et al. 2019). Ramesh et al. Anatase type $\mathrm{TiO}_{2}$ and $\mathrm{Li}_{2} \mathrm{CO}_{3}$ were mixed, ground and heated in an alumina crucible at $700{ }^{\circ} \mathrm{C}$ in air to obtain the lithium ion sieve precursor $\left(\mathrm{Li}_{2} \mathrm{CO}_{3}\right)$. The measured adsorption capacity of the adsorbent is $32.6 \mathrm{mg} \cdot \mathrm{g}^{-1}$ (Garcia et al. 2018b). Unfortunately, most of the known lithium ion sieves are powdered, which is not conducive to the mass production of ion sieves in practical applications. Therefore, the preparation of mesoporous nanomaterials to synthesize lithium ion sieve is of special significance(Elik et al. 2018). Cellulose is a polysaccharide with a wide coverage and the largest content in nature( $\mathrm{Li}$ et al. 2019). Rich content and low price make it naturally attract the attention of scientific researchers in recent years. However, natural cellulose has some impurities such as lignin and hemicellulose, especially the coarse fiber diameter of natural cellulose, which affects the performance of cellulose(Tomer and Malik 2019). With the in-depth of bacterial cellulose (BC) synthesized by microorganisms under different conditions, the chemical structure of BC is the same as that of plant cellulose(Aimar et al. 2019). The difference is that $\mathrm{BC}$ has the advantages of higher purity and finer fiber diameter than plant cellulose. Due to the formation of ultrafine network structure of bacterial cellulose and the "nano-effect", bacterial cellulose has the characteristics of high water absorption and water retention, high permeability to liquids and gases, high wet strength, and in-situ processing and moulding, especially in wet state. High purity and excellent performance can be widely used in many fields.

As far as we know, there is no report about the preparation of $\mathrm{Li}_{2} \mathrm{TiO}_{3}$ by hydrothermal reaction using bacterial cellulose as template. Thus, in this research, We first proposed using $\mathrm{BC}$ as a template to form titanium dioxide mesoporous membrane on the substrate. Then, the precursor of $\mathrm{Li}_{2} \mathrm{TiO}_{3}$ was preliminarily obtained by hydrothermal method with $\mathrm{LiOH}(G a r c i a$ et al. 2018a). The morphology of the precursor was stabilized by calcination at high temperature and the lithium ion sieve with mesoporous shape was obtained by acid elution. Finally, we also proved the 
excellent adsorption effect of this lithium ion sieve using bacterial cellulose as template in the adsorption experiment, and expected its application prospects.

\section{Experimental}

\subsection{Synthesis of the $\mathrm{Li}_{2} \mathrm{TiO}_{3}$}

Bacterial cellulose (BC) hydrogel, titanium ethoxide (TEOT), lithium hydroxide $(\mathrm{LiOH})$. Deionized water was used in all experiments. Hydrochloric acid $(\mathrm{HCl})$ and other drugs used are analytically pure, without the need for further processing and purification. Bacterial cellulose (BC) hydrogel was placed in deionized water for 15 min to achieve swelling effect. After freezing with liquid nitrogen and freeze-drying, the bacterial cellulose (BC) aerogel with a network structure was obtained. The bacterial cellulose (BC) aerogel was immersed in titanium ethoxide (TEOT) solution for $2 \mathrm{~h}$. Then, after alternately rinsing with ethanol and ultrapure water for 4 to 5 times, it was placed in ultrapure water and mechanically stirred for 2 hours, and the product was repeatedly washed with deionized water. Finally, the bacterial cellulose film material $\mathrm{TiO}_{2} / \mathrm{BC}$ wrapped in $\mathrm{TiO}_{2}$ was obtained after drying in the oven(Zhu et al. 2020). $\mathrm{TiO}_{2}$ with a weight of $0.826 \mathrm{~g}$ was obtained by calcining at $600{ }^{\circ} \mathrm{C}$ for $6 \mathrm{~h}$ at $4{ }^{\circ} \mathrm{C} / \mathrm{min}$ in a tubular furnace. The $\mathrm{TiO}_{2}$ was dissolved in $10.45 \mathrm{ml}$ of $\mathrm{H}_{2} \mathrm{O}$ with $0.5 \mathrm{~g}$ of $\mathrm{LiOH}$. The $\mathrm{Li}$ : Ti molar ratio of 2:1, unstable spinel $\mathrm{Li}_{2} \mathrm{TiO}_{3}$ is obtained after hydrothermal reaction at $180{ }^{\circ} \mathrm{C}$ for $18 \mathrm{~h}$. The stable spinel $\mathrm{Li}_{2} \mathrm{TiO}_{3}$ was obtained after being calcined at $4{ }^{\circ} \mathrm{C} / \mathrm{min}$ at $600{ }^{\circ} \mathrm{C}$ for $6 \mathrm{~h}$ in a tube furnace.

\subsection{Synthesis of the $\mathrm{H}_{2} \mathrm{TiO}_{3}$}

$\mathrm{Li}_{2} \mathrm{TiO}_{3}$ was eluted in the $0.1 \mathrm{~mol} / \mathrm{L}$ of $\mathrm{HCl}$ at $65^{\circ} \mathrm{C}$ for $12 \mathrm{~h}$, and then the eluate was changed again to ensure the elution. Finally, the eluted product was washed and filtered with ultra-pure water and dried in an oven at $70{ }^{\circ} \mathrm{C}$. The final product was spinel titanium oxide ion screen. The titanium based lithium ion sieves $\mathrm{H}_{2} \mathrm{TiO}_{3}$ with high adsorption and specific adsorption for $\mathrm{Li}^{+}$were obtained.

\section{Results and discussion}

\section{Characterizations of $\mathrm{Li}_{2} \mathrm{TiO}_{3}$ and $\mathrm{H}_{2} \mathrm{TiO}_{3}$}

In order to analyze functional groups of $\mathrm{TiO}_{2}, \mathrm{Li}_{2} \mathrm{TiO}_{3}$ and $\mathrm{H}_{2} \mathrm{TiO}_{3}$, FT-IR analysis was performed and presented in Figure 1. Broad peaks at 3448 and $2925 \mathrm{~cm}^{-1}$ 
were observed for three materials' FT-IR spectra, which can be interpreted as O-H and $\mathrm{C}-\mathrm{H}$ stretching vibrations, respectively. Among them, $\mathrm{OH}$ peak was observed. This peak was due to the isolated $\mathrm{O}-\mathrm{H}$ bond not participating in the interaction with other hydroxyl groups. In addition, compared with the FT-IR spectra of $\mathrm{TiO}_{2}$, the new peaks at 1438 and $1508 \mathrm{~cm}^{-1}$ appeared after lithium insertion, which belonged to the characteristics vibration of $\mathrm{Li}-\mathrm{O}-\mathrm{Ti}$ band. It indicates that the precursor $\left(\mathrm{Li}_{2} \mathrm{TiO}_{3}\right)$ was formed. In the case of $\mathrm{Li}_{2} \mathrm{TiO}_{3}$, the disappearance of peaks at 1438 and $1508 \mathrm{~cm}^{-1}$ show successful elution of lithium ions, and the preparation of lithium ion sieve $\left(\mathrm{H}_{2} \mathrm{TiO}_{3}\right)$ was completed. As can be seen in the SEM diagram in Figure 2(a), the titania films formed with bacterial cellulose as template feature pronounced high pore volume network structure. After the hydrothermal calcination with $\mathrm{LiOH}$, the films become denser with crystals grow and aggregate, resulting in the formation of spinel $\mathrm{Li}_{2} \mathrm{TiO}_{3}$ (Figure $2 \mathrm{~b}$ ). The nitrogen sorption data of $\mathrm{H}_{2} \mathrm{TiO}_{3}$ showed a BET surface area of $27.4006 \mathrm{~m}^{2} / \mathrm{g}$. Based on the adsorption desorption isotherm of nitrogen (Figure 3) shows that the pore structure in the material is consistent with the results of SEM. It can further be inferred that bacterial cellulose as template is effective.

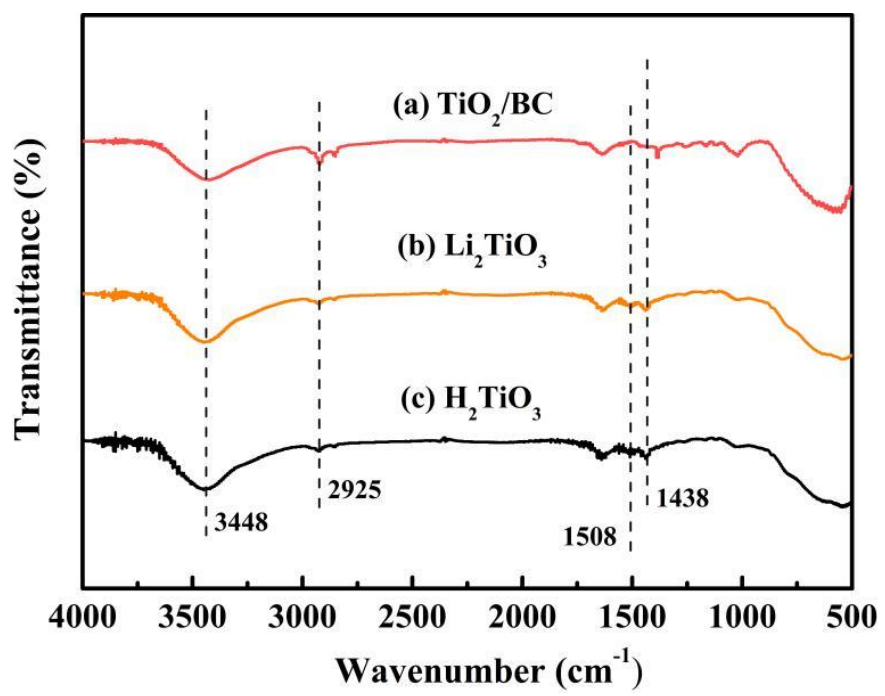

Fig. 1 (a) FT-IR spectra of $\mathrm{TiO}_{2} / \mathrm{BC}$; (b) $\mathrm{Li}_{2} \mathrm{TiO}_{3}$; (c) $\mathrm{H}_{2} \mathrm{TiO}_{3}$ 


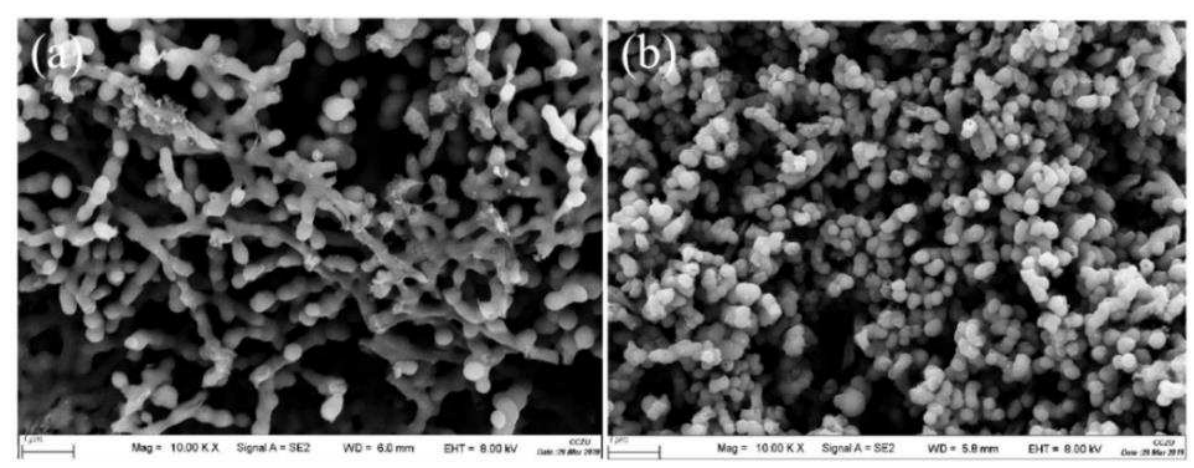

Fig. 2 (a) SEM image of $\mathrm{TiO}_{2} / \mathrm{BC}$; (b) SEM images of $\mathrm{Li}_{2} \mathrm{TiO}_{3}$.

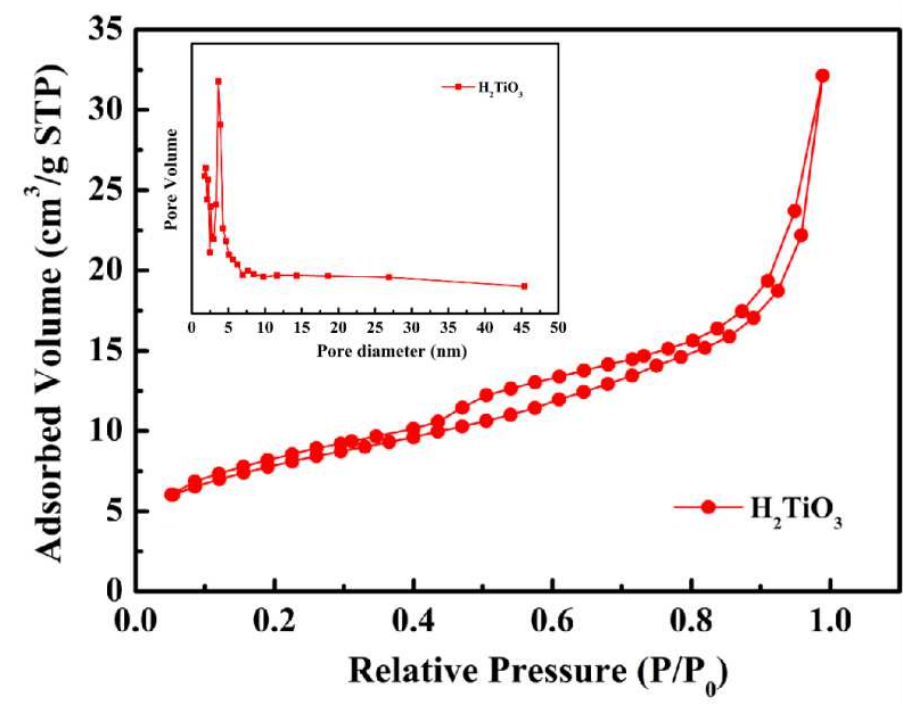

Fig. 3 Nitrogen adsorption-desorption isotherm of $\mathrm{H}_{2} \mathrm{TiO}_{3}$. Inset showing Inset showing pore size distributions.

As shown in Figure. 4, XRD pattern of the $\mathrm{Li}_{2} \mathrm{TiO}_{3}$ before calcination, $\mathrm{Li}_{2} \mathrm{TiO}_{3}$ after calcination and $\mathrm{H}_{2} \mathrm{TiO}_{3}$ were collected at the $2 \theta$ angle from 10 to $70^{\circ}$. In the XRD pattern of the $\mathrm{Li}_{2} \mathrm{TiO}_{3}$, a new diffraction peak at (002) appeared after calcination, which belonged to the growth of (002) diffraction peak needs higher calcination temperature(Gebreslase and Technology 2018). The occurrence of diffraction peaks of (002), (-133), (-206) and (062) can be seen in the Figure 4(b), indicating that $\mathrm{Li}^{+}$is orderedly inserted into $\mathrm{TiO}_{2}$, which were matched well with the pure monoclinic crystal of $\mathrm{Li}_{2} \mathrm{TiO}_{3}$ (Peng et al. 2019). After eluting, the position of the diffraction peaks can be observed to be about the same, and the diffraction peak of (-133) and (206) almost disappears, which proves on exchange occurs in $\mathrm{Li}^{+} / \mathrm{H}^{+}$and the formation of $\mathrm{H}_{2} \mathrm{TiO}_{3}$ structure. 


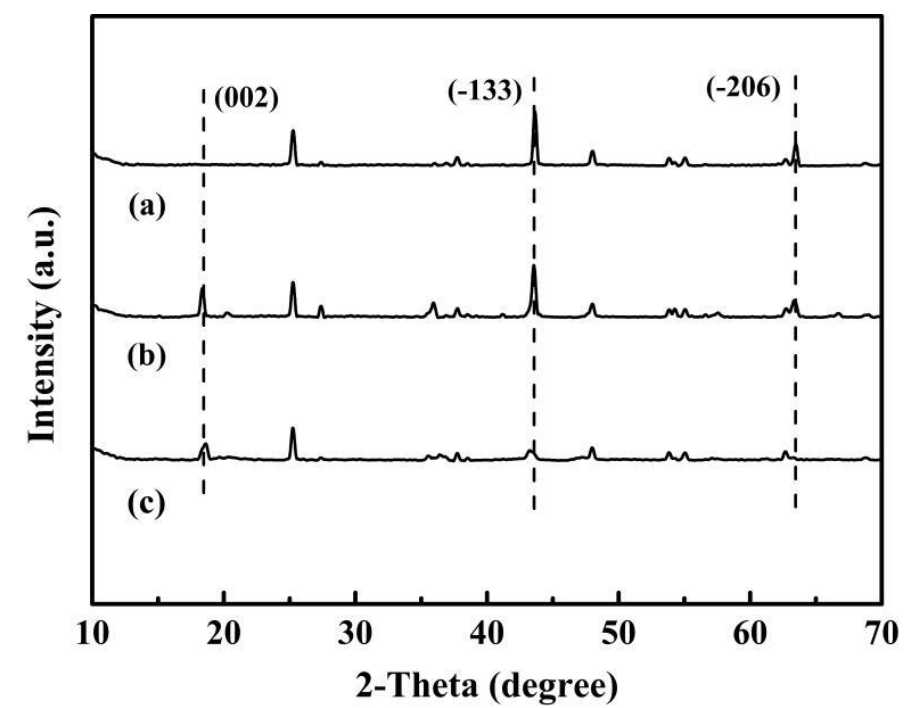

Fig. 4 (a) XRD patterns of $\mathrm{Li}_{2} \mathrm{TiO}_{3}$ before calcination; (b) $\mathrm{Li}_{2} \mathrm{TiO}_{3}$ after calcination; (c) $\mathrm{H}_{2} \mathrm{TiO}_{3}$

\section{Adsorption performance of $\mathrm{H}_{2} \mathrm{TiO}_{3}$}

\subsection{Effect of pH}

Here we briefly explore the relationships between $\mathrm{Li}^{+}$and its adsorption mechanism, in which the $\mathrm{pH}$ value dominates the study. The $\mathrm{pH}$ value is particularly critical for the adsorption capacity of $\mathrm{H}_{2} \mathrm{TiO}_{3}$. As shown in Fig. 5a, with the $\mathrm{pH}$ value increases, the adsorption amount of $\mathrm{Li}^{+}$also increases gradually( $\mathrm{Sw}$ et al.). It can be seen that the adsorption of $\mathrm{Li}^{+}$is favorable under alkaline condition. In order to avoid adding more $\mathrm{NaOH}$ to adjust the higher $\mathrm{pH}$ concentration, thus increasing the effect of cations in the solutions and considering that the excessively high $\mathrm{pH}$ value is not conducive to mass production in industrial applications. Therefore, the recovery of $\mathrm{Li}^{+}$in this experiment was mainly carried out at $\mathrm{pH} 11$. Fig. $5 \mathrm{~b}$ shows the zeta potential test of lithium ion sieve. with the $\mathrm{pH}$ increases, the value of the electrostatic negative charge value on the material also gradually increases. It keeps coincident with the $\mathrm{pH}$ tests results. 

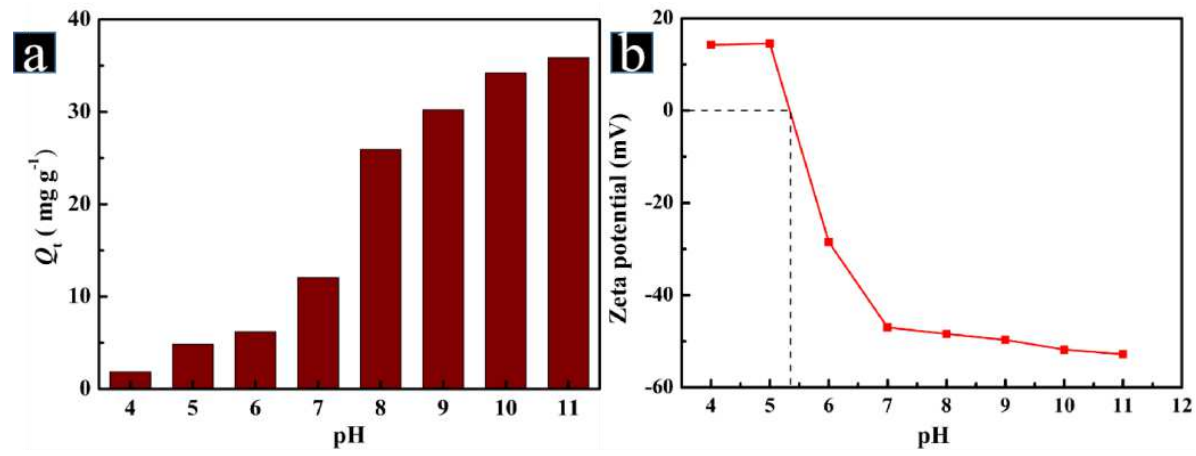

Fig. 5 (a) Effect of pH on adsorption capacities (b) Zeta potential measurement of $\mathrm{H}_{2} \mathrm{TiO}_{3}$

\subsection{Adsorption kinetics}

Through the adsorption kinetics experiment, the connection between the adsorption amount $\left(Q_{\mathrm{t}}\right)$ and the adsorption time $(\mathrm{t})$ was analyzed. We can see in Figure 6 , the adsorption curve of the ion sieve adsorbent increased rapidly from the begining, reaching about $80 \%$ of the maximum adsorption capacity at $200 \mathrm{~min}$, then the adsorption curve increases slightly and eventually gradually tends to adsorption equilibrium at about $6 \mathrm{~h}$. The adsorption process of ionic sieve $\mathrm{H}_{2} \mathrm{TiO}_{3}$ in $\mathrm{LiCl}$ solution was fitted by pseudo-first-order kinetic model (PFOKM), pseudo-secondorder kinetic model (PSOKM) to explore the adsorption rate constant and mechanism. The fittting equation of the PFOKM and PSOKM as follows:

$$
\begin{aligned}
& Q_{\mathrm{t}}=Q_{\mathrm{e}}-Q_{\mathrm{e}} e^{-k_{1} t} \\
& Q_{\mathrm{t}}=\frac{k_{2} Q_{\mathrm{e}}^{2} t}{1+k_{2} Q_{\mathrm{e}} t}
\end{aligned}
$$

Where, $Q_{\mathrm{t}}\left(\mathrm{mg} \cdot \mathrm{g}^{-1}\right)$ corresponds to the amount of $\mathrm{Li}^{+}$adsorbed at time $\mathrm{t}(\mathrm{min})$ and $Q_{\mathrm{e}}\left(\mathrm{mg} \cdot \mathrm{g}^{-1}\right)$ corresponds to the amount of adsorption at equilibrium. $k_{1}\left(\min ^{-1}\right)$ and $k_{2}$ $\left(\mathrm{g} \cdot \mathrm{mg}^{-1} \cdot \mathrm{min}^{-1}\right)$ are the rate constants of the PFOKM and PSOKM, respectively. In addition, the $\mathrm{h}\left(\mathrm{mg} \cdot \mathrm{g}^{-1} \cdot \mathrm{min}^{-1}\right)$ and $\mathrm{t}_{1 / 2}(\mathrm{~min})$ of the PSOKM are listed in the following formulas (3) and (4):

$$
\begin{aligned}
& \mathrm{h}=k_{2} Q_{\mathrm{e}}^{2} \\
& t_{1 / 2}=\frac{1}{k_{2} Q_{\mathrm{e}}}
\end{aligned}
$$

The kinetic curve of adsorption was fitted by PFOKM and PSOKM. The fitting curve and corresponding parameters are presented in Figure 6 and Table 1, respectively. Obviously, the correlation coefficient of $R^{2}$ fitted by PSOKM is larger 
215 than the correlation coefficient of $R^{2}$ fitted by PFOKM, which better matches the experimental data.

At the same time, the equilibrium adsorption amount calculated based on the PFOKM and the PSOKM. Compared with the actual values, the results of the pseudo219 secondary dynamics model are closer to reality. Therefore, we believe that PSOKM is more in line with the adsorption of ion sieve $\mathrm{H}_{2} \mathrm{TiO}_{3}$ in $\mathrm{LiCl}$ solution. This further

221 illustrates that the adsorption process of $\mathrm{Li}^{+}$by $\mathrm{H}_{2} \mathrm{TiO}_{3}$ is mainly completed under the 222 chemical action.

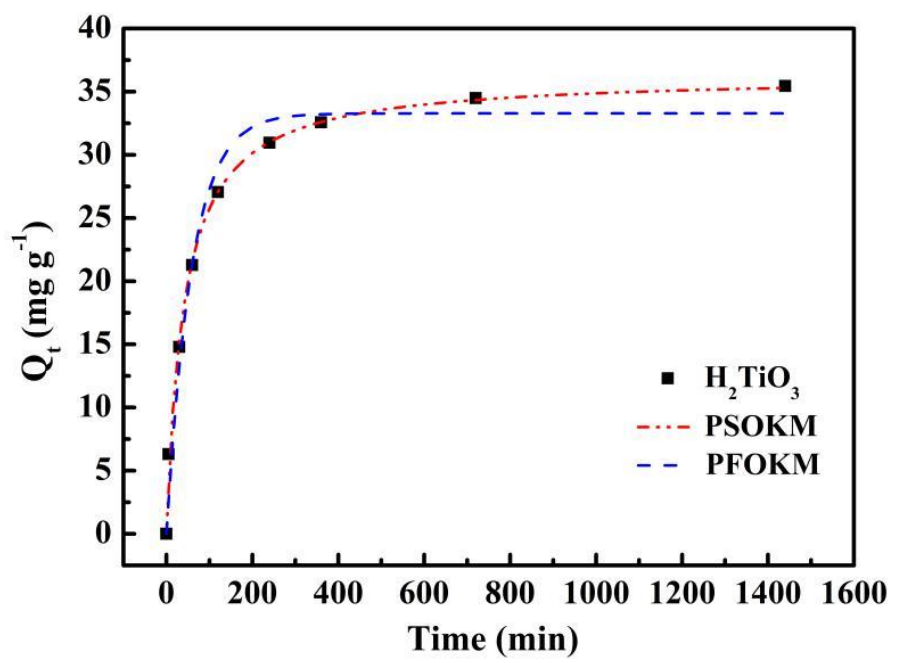

Fig.6 Kinetic data and modeling for the adsorption of $\mathrm{Li}^{+}$: Fitting curves of PFOKM and PSOKM Table 1. Kinetic parameters for the PFOKM and PSOKM

\begin{tabular}{cccccccc}
\hline & & \multicolumn{3}{c}{ PFOKM } & \multicolumn{4}{c}{ PSOKM } \\
\cline { 3 - 8 } Sorbents & $Q_{e, \text { exp }}\left(m g \cdot g^{-1}\right)$ & $\begin{array}{c}Q_{\mathrm{e}, \mathrm{c}} \\
\left(\mathrm{mg} \cdot \mathrm{g}^{-1}\right)\end{array}$ & $\begin{array}{c}k_{1} \\
\left(\mathrm{~min}^{-1}\right)\end{array}$ & $R^{2}$ & $\begin{array}{c}Q_{\mathrm{e}, \mathrm{c}} \\
\left(\mathrm{mg} \cdot \mathrm{g}^{-1}\right)\end{array}$ & $\begin{array}{c}k_{2} \times 10^{-2} \\
\left(\mathrm{~g} \cdot \mathrm{mg}^{-1} \cdot \mathrm{min}^{-1}\right)\end{array}$ & $R^{2}$ \\
$\mathrm{H}_{2} \mathrm{TiO}_{3}$ & 35.45 & 33.28 & 0.0172 & 0.975 & 36.29 & 0.068 & 0.991 \\
\hline
\end{tabular}

\subsection{Adsorption isotherms}

By statically testing equilibrium adsorption data and adsorption curves in $\mathrm{LiCl}$ solutions (100-2000 $\left.\mathrm{mg} \cdot \mathrm{L}^{-1}\right)$, so as to explore the equilibrium concentration and adsorption amount of the adsorbent in different concentrations of lithium-containing solutions. Among them, from the curve fitted by Langmuir and Freundlich equation (Figure 7), the adsorption effect will become higher with the increase of $\mathrm{Li}^{+}$ concentration. The saturation adsorption capacity of $\mathrm{H}_{2} \mathrm{TiO}_{3}$ is $35.45 \mathrm{mg} \cdot \mathrm{g}^{-1}$. The related isothermal constants are listed Table 2. It is not difficult to see that the 
correlation parameters of the Langmuir and Freundlich adsorption isotherm models are $R^{2}=0.996$ and $R^{2}=0.978$, respectively. In comparison, the Langmuir isotherm adsorption model can better match the experimental data, which also corresponds to the single layer adsorption. This indicates that fitting experimental data with Langmuir equation is closer to actual data. Hence, the lithium ion sieve is known as an adsorbent with excellent performance in extracting $\mathrm{Li}^{+}$. Experimental data fit via Langmuir and Freundlich models, which were calculated by Eqs. (5) and (6):

$$
\begin{gathered}
Q_{\mathrm{e}}=\frac{K_{\mathrm{L}} Q_{\mathrm{m}} C_{\mathrm{e}}}{1+K_{\mathrm{L}} C_{\mathrm{e}}} \\
Q_{\mathrm{e}}=K_{\mathrm{F}} C_{\mathrm{e}}^{1 / n}
\end{gathered}
$$

In the formula, $Q_{\mathrm{m}}\left(\mathrm{mg} \cdot \mathrm{g}^{-1}\right)$ is expressed as the maximum amount of $\mathrm{H}_{2} \mathrm{TiO}_{3}$ to $\mathrm{Li}^{+} . K_{\mathrm{L}}\left(\mathrm{L} \mathrm{g}^{-1}\right)$ corresponds to the Langmuir isotherm constant. $K_{\mathrm{F}}\left(\mathrm{mg} \cdot \mathrm{g}^{-1}\right)$ corresponds to Freundlich isotherm direction constant, 1/n corresponds to the effect of concentration on the amount of adsorption, $R_{\mathrm{L}}$ is used as a separation factor to identify the merits of $\mathrm{H}_{2} \mathrm{TiO}_{3}$, which the calculation formula of $R_{\mathrm{L}}$ is listed in formula (7):

$$
R_{\mathrm{L}}=\frac{1}{1+C_{\mathrm{m}} K_{\mathrm{L}}}
$$

In this formula, $\mathrm{C}_{\mathrm{m}}$ is explained as the maximum initial concentration of $\mathrm{Li}^{+}$.

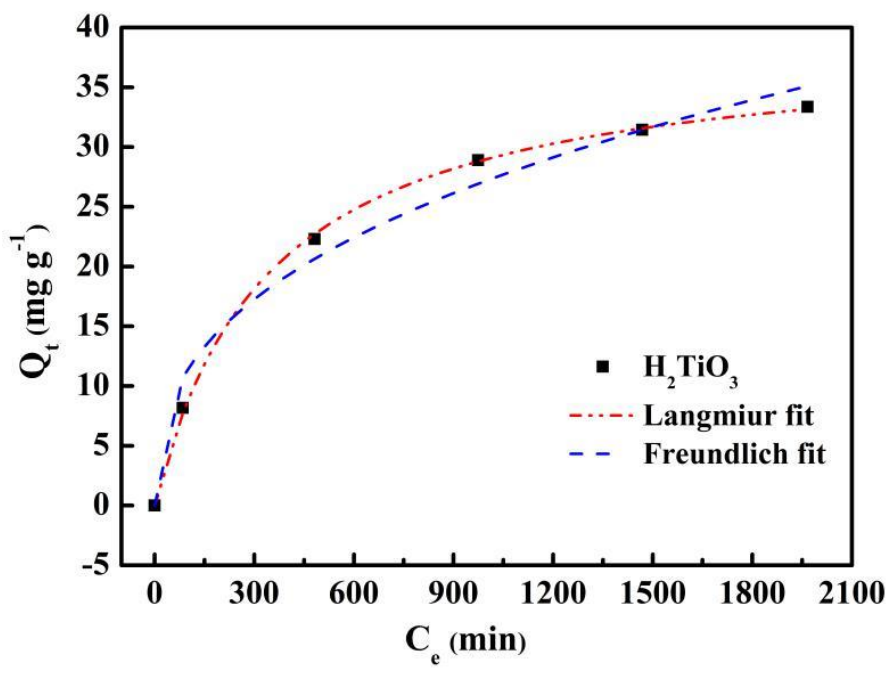

Fig.7 Isotherm model fitting of on $\mathrm{H}_{2} \mathrm{TiO}_{3}$ adsorbing $\mathrm{Li}^{+}$. 
Table 2. Adsorption equilibrium constants of Langmuir and Freundlich models

\begin{tabular}{ccccccc}
\hline & \multicolumn{3}{c}{ Langmuir isotherm model } & \multicolumn{3}{c}{ Freundlich isotherm model } \\
\cline { 2 - 6 } Sorbents & $\begin{array}{c}Q_{\mathrm{m}} \\
\left(\mathrm{mg} \cdot \mathrm{g}^{-1}\right)\end{array}$ & $\begin{array}{c}K_{\mathrm{L}} \\
\left(\mathrm{L} \cdot \mathrm{mg}^{-1}\right)\end{array}$ & $R^{2}$ & $\begin{array}{c}\mathrm{K}_{\mathrm{F}} \\
\left(\mathrm{mg} \cdot \mathrm{g}^{-1}\right)\end{array}$ & $1 / \mathrm{n}$ & $R^{2}$ \\
& 38.96 & 0.003 & 0.998 & 2.01 & 0.38 & 0.948 \\
\hline
\end{tabular}

\subsection{Effect of temperature}

Further, considering the influence of thermal motion characteristics on the adsorption efficiency. Therefore, we explored the effect of $\mathrm{H}_{2} \mathrm{TiO}_{3}$ on $\mathrm{Li}^{+}$adsorption at different temperatures $(298.15 \mathrm{~K}, 308.15 \mathrm{~K}$, and $318.15 \mathrm{~K})$ through thermodynamic experiments. $\Delta \mathrm{G}^{\circ}$ is calculated from the Gibbs free energy formula, and the change of $\mathrm{Q}_{\mathrm{e}}$ with temperature was studied (Fig. 8 (a)). $\Delta \mathrm{H}^{\circ}$ and $\Delta \mathrm{S}^{\circ}$ are calculated by the $\ln \mathrm{K}^{\circ}$ equation, and the change of van't Hoff plot of $\ln \mathrm{K}^{\circ}$ to $1 / \mathrm{T}$ was studied (Fig. 8 (b))(Zhang et al.). The results of the thermodynamic parameters of the ion sieve are shown in Table 3. It can be observed that at a temperature of $298.15-318.15 \mathrm{~K}$, the value of $\Delta \mathrm{G}^{\circ}$ is maintained at -3.85 to $-4.73 \mathrm{~kJ} \cdot \mathrm{mol}^{-1}$, and is always negative. It indicates that as the temperature increases, the adsorption capacity will gradually become higher. That is to say, the adsorption of $\mathrm{Li}^{+}$is a spontaneous process. At the same time, $\Delta \mathrm{H}^{\circ}$ is always positive, which can be explained as an endothermic adsorption process, indicating that the $\mathrm{Li}^{+}$adsorption effect will increase with increasing temperature. Hence, we believe that the adsorption of $\mathrm{Li}^{+}$on the ion sieve is a spontaneous endothermic process.
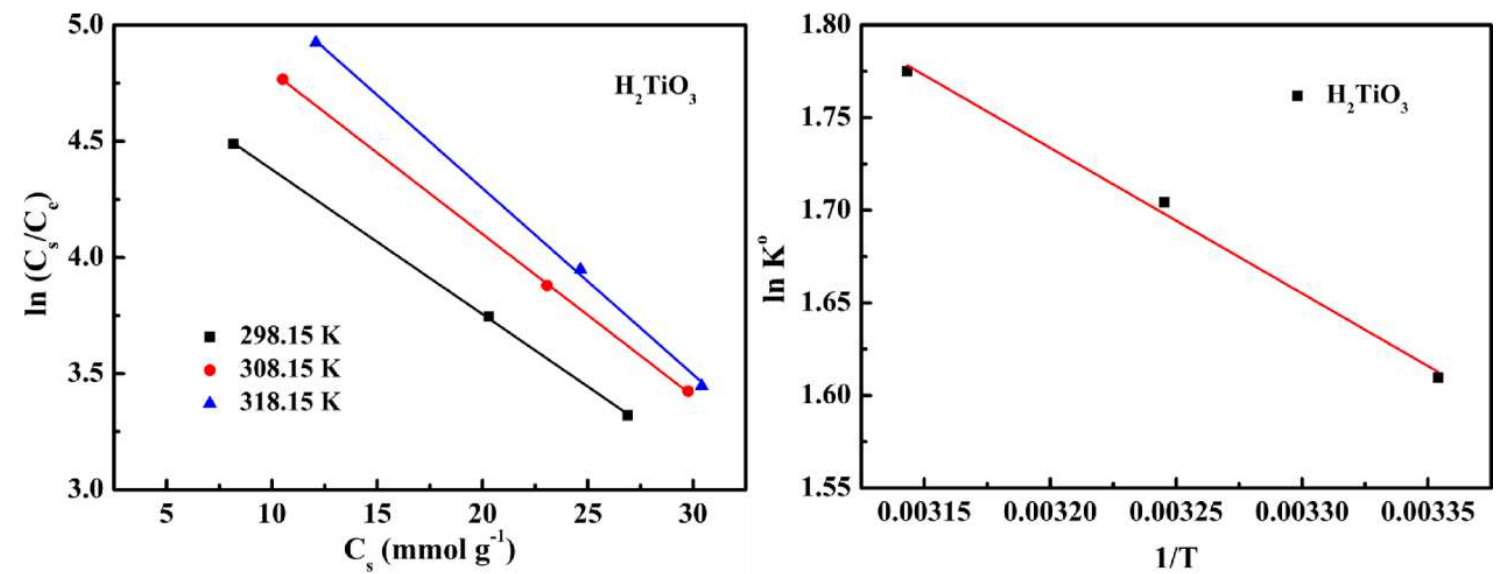

Fig. 8 Thermodynamic properties of $\mathrm{Li}^{+}$on $\mathrm{H}_{2} \mathrm{TiO}_{3}$ at $298.15,308.15$, and $318.15 \mathrm{~K}$ 
Table 3. Thermodynamic parameters for $\mathrm{Li}^{+}$adsorption

\begin{tabular}{ccccccc}
\hline Sorbents & $\begin{array}{c}\Delta H^{o} \\
\left(\mathrm{~kJ} \mathrm{~mol}^{-1}\right)\end{array}$ & $\begin{array}{c}\Delta S^{o} \\
\left(\mathrm{~J} \mathrm{~mol}^{-1}\right)\end{array}$ & $\begin{array}{c}T \\
(K)\end{array}$ & $K^{o}$ & $\begin{array}{c}\Delta G^{o} \\
\left(\mathrm{~kJ} \mathrm{~mol}^{-1}\right)\end{array}$ & $R^{2}$ \\
\hline \multirow{2}{*}{$\mathrm{H}_{2} \mathrm{TiO}_{3}$} & \multirow{2}{*}{6.54} & 35.31 & 298.15 & 5.00 & -3.99 & \\
& & & 308.15 & 5.50 & -4.37 & 0.992 \\
\hline
\end{tabular}

272

273

274

275

\subsection{Selective and reusability tests}

Through selective experiments to determine whether $\mathrm{H}_{2} \mathrm{TiO}_{3}$ has a specific adsorption selectivity for $\mathrm{Li}^{+}$, we simulated salt lake brine for competitive adsorption experiment, and tested the adsorption performance of $\mathrm{H}_{2} \mathrm{TiO}_{3}$ to $\mathrm{Na}^{+}, \mathrm{Mg}^{2+}, \mathrm{K}^{+}, \mathrm{Ca}^{2+}$, $\mathrm{Li}^{+} . K_{\mathrm{d}}\left(\mathrm{mL} \cdot \mathrm{g}^{-1}\right)$ is the partition coefficient and $k$ as the selectivity coefficient were used as indicators to evaluate the selectivity of $\mathrm{H}_{2} \mathrm{TiO}_{3}$. According to the magnitude of the comparison $K_{\mathrm{d}}$ value, the adsorption selection performance of $\mathrm{H}_{2} \mathrm{TiO}_{3}$ for $\mathrm{Li}^{+}$ can be judged. From the experimental results, we can clearly observe that when the adsorption reaches equilibrium, the adsorption effect and partition coefficient $\left(K_{\mathrm{d}}\right)$ of $\mathrm{Li}^{+}$by $\mathrm{H}_{2} \mathrm{TiO}_{3}$ are several times that of other metal ions. Based on this, it can be determined that the lithium ion sieve $\mathrm{H}_{2} \mathrm{TiO}_{3}$ specifically adsorbs $\mathrm{Li}^{+}$. The selectivity of ion sieve for $\mathrm{Li}^{+} \mathrm{K}^{+} \mathrm{Ca}^{2+} \mathrm{Na}^{+} \mathrm{Mg}^{2+}$ was assessed by distribution coefficient $\left(K_{\mathrm{d}}\right.$, $\left.\mathrm{mL} \mathrm{g}^{-1}\right)$, which is listed in formula (8):

$$
k_{\mathrm{d}}=\frac{C_{\mathrm{o}}-C_{\mathrm{f}}}{C_{\mathrm{f}}} \times \frac{V}{m}
$$

In this formula, $C_{0}$ is interpreted as the initial concentration of five ionic solutions, and $C_{\mathrm{f}}$ represents the final concentration of each ionic solution.

The industrial feasibility of lithium ion sieve was verified by adsorption cycle experiment, so that the production cost was minimized. After each adsorption, the eluent $(0.1 \mathrm{M} \mathrm{HCl})$ desorbs the adsorbent. Such a process is called a cycle. The experimental results are shown in Fig. 11. After 5 cycles, the capacity of the adsorbent remained above $82 \%$ of the initial value. All these results confirm that $\mathrm{H}_{2} \mathrm{TiO}_{3}$ has a good cycle adsorption potential for $\mathrm{Li}^{+}$. 


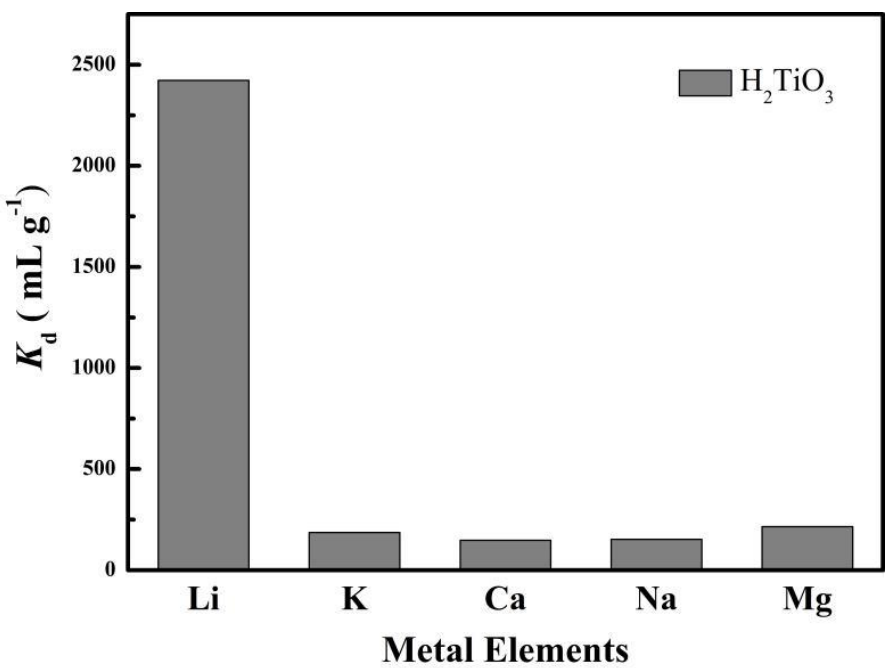

Fig. $9 K_{\mathrm{d}}$ values of $\mathrm{H}_{2} \mathrm{TiO}_{3}$ for a mixture of $\mathrm{Na}^{+}, \mathrm{Mg}^{2+}, \mathrm{K}^{+}, \mathrm{Ca}^{2+}, \mathrm{Li}^{+}$

Table 4. $K_{\mathrm{d}}$ and $\mathrm{k}$ values of $\mathrm{H}_{2} \mathrm{TiO}_{3}$

\begin{tabular}{cccc}
\hline \multirow{2}{*}{ Cation } & \multicolumn{3}{c}{$\mathrm{H}_{2} \mathrm{TiO}_{3}$} \\
\cline { 2 - 4 } $\mathrm{Li}^{+}$ & $C_{\mathrm{f}}\left(\mathrm{mg} \cdot \mathrm{L}^{-1}\right)$ & $K_{\mathrm{d}}\left(\mathrm{mL} \cdot \mathrm{g}^{-1}\right)$ & $k$ \\
$\mathrm{~K}^{+}$ & 14.609 & 2422.548 & \\
$\mathrm{Ca}^{2+}$ & 48.059 & 40.388 & 0.017 \\
$\mathrm{Na}^{+}$ & 45.961 & 87.879 & 2.176 \\
$\mathrm{Mg}^{2+}$ & 47.634 & 49.670 & 0.565 \\
& 44.087 & 134.121 & 2.700 \\
\hline
\end{tabular}

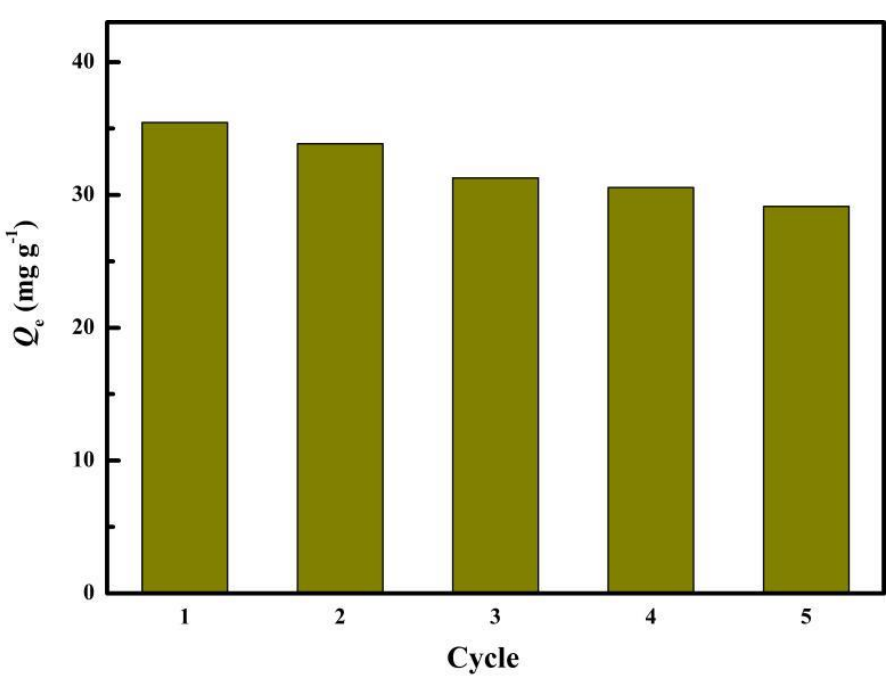

Fig.10 Regeneration of $\mathrm{H}_{2} \mathrm{TiO}_{3} 5$ cycles.

\section{Conclusion}

In this study, a lithium ion sieve with bacterial cellulose as a template was 302 successfully prepared and used for the specific adsorption and separation of $\mathrm{Li}^{+}$from 303 seawater and salt lake brine. And it shows excellent periodicity and stability in 
adsorption, elution and circulation experiments. At the same time, using bacterial cellulose as a biological template, the preparation of mesoporous titanium-based lithium ion sieve was realized. Compared with the previous methods of assembling lithium-ion sieve, the ion sieve prepared by using cellulose as biological template not only has a slightly higher adsorption capacity, but also has the mesoporous structure provided by bacterial cellulose, which provides more possibilities for future research. Therefore, we believe that the spinel-type titanium dioxide ion sieve prepared by this method has broad application prospects and is expected to be widely used.

\section{Acknowledgements}

This work was funded through National Natural Science Foundation of China [No.21808018, 21876015, 21878026]; Jiangsu Provincial Science and Technology Department Industry Foresight Plan [No. FZ20180422]; Natural science research project of colleges and universities in Jiangsu Province [No.18KJB610002] and Applied Basic Research in Changzhou [No. CJ20180055]. The authors also expressed their gratitude to other testers in this study.

\section{Declarations}

\section{Conflict of interest}

The authors declare that they have no conflict of interest.

\section{Ethical approval}

The article does not contain any experiments with human participants or animals performed by any of the authors.

\section{Informed consent}

Informed consent was obtained from all individual participants included in the st udy

\section{References}

Aimar A, Palermo A, Innocenti BJJoHE (2019) The Role of 3D Printing in Medical Applications: A State of the Art 2019:1-10

Argurio P, Tagarelli A, Molinari R (2019) A Study on Neodymium Recovery from Aqueous Solutions for Designing a New Generation of Sandwich Liquid Membrane 
DING et al. (2018) Genesis of the Weiquan Ag-Polymetallic Deposit in East Tianshan, China:Evidence from Zircon U-Pb Geochronology and C-H-O-S-Pb Isotope Systematics v.92:222-244

Elik A, Topu G, Isik T, Baba A, Horzum N, De mir MM Investigation of Lithium Sorption Efficiency Using SWCNT Functionalized Electrospun Fiber Mats from the Hypersaline Geothermal Brine. In: Materials Science Forum, 2018.

Gao A, Sun Z, Li S, Hou X, Li H, Wu Q, Xi XJDT (2018) The mechanism of manganese dissolution on Li1.6Mn1.6O4 ion sieves with $\mathrm{HCl}$ 47:3864-3871

Garay-Rodríguez L, Murcia-López S, Andreu T, Moctezuma E, Torres-Martínez L, Morante JRJC (2019) Photocatalytic Hydrogen Evolution Using Bi-Metallic (Ni/Pt) Na2Ti3O7 Whiskers: Effect of the Deposition Order 9

Garcia, Eric, M., Taroco, Hosane, Recycling AJ (2018a) Water Electrolysis Anode Based on 430 Stainless Steel Coated with Cobalt Recycled from Li-Ion Batteries 3:42-42

Garcia, Eric M, Taroco, Hosane A, Teixeira, Rodrigo GJR (2018b) Fast Electrochemical Method for Organic Dye Decolorization Using Recycled Li-Ion Batteries

Gebreslase GAJJoMS, Technology (2018) Review on Membranes for the Filtration of Aqueous Based Solution: Oil in Water Emulsion 08

Grágeda M, González A, Grágeda M, Ushak SJIJoER (2018) Purification of brines by chemical precipitation and ion-exchange processes for obtaining battery-grade lithium compounds

Gza B, Dt A, Mb AJAG (2020) Solvent extraction of lithium from simulated shale gas produced water with a bifunctional ionic liquid - ScienceDirect 123

Img A, Avv A, Vmv B (2021) Thermal dependency of Li + -ion conductivity in Li 2 O-Fe 2 O 3 -Al 2 O 3 ceramics

Li M, Miao Y, Zhai X, Yin Y, Liu ZJM, design (2019) Preparation of and research on bioinspired graphene oxide/nanocellulose/polydopamine ternary artificial nacre 181:107961

Lihua et al. (2018) New Insights into the Application of Lithium-Ion Battery Materials: Selective Extraction of Lithium from Brines via a Rocking-Chair Lithium-Ion Battery System

Liu L, Feng X, Rahe C, Li W, Ouyang MJJoEC (2021) Internal short circuit evaluation and corresponding failure mode analysis for lithium-ion batteries

Ma L, Xi X, Wang K, Zhao LJRoCI (2018) Adsorption of Li by a lithium ion-sieve using a buffer system and application for the recovery of Li from a spent lithium-ion battery:1-19

Michel C, Barré Y, Guiza MB, Dieuleveult CD, Windt LD, Grandjean AJCEJ (2018) Breakthrough studies of the adsorption of Cs from freshwater using a mesoporous silica material containing ferrocyanide 339:288-295

Peng C, Liu F, Wang Z, Wilson BP, Lundstrom MJJoPS (2019) Selective extraction of lithium (Li) and preparation of battery grade lithium carbonate ( $\mathrm{Li} 2 \mathrm{CO} 3$ ) from spent Li-ion batteries in nitrate system 415:179-188

Romero VCE, Tagliazucchi M, Flexer V, Ca Lvo EJJJoTES (2018) Sustainable Electrochemical Extraction of Lithium from Natural Brine for Renewable Energy Storage 165:A2294-A2302

Sasaki K, Yu Q (2015) Synthesis of a Biotemplated Lithium Ion-Sieve Derived from Fungally Formed Birnessite. Advances in the Environmental Biogeochemistry of Manganese Oxides,

Song JF, Nghiem LD, Li XM, He TJESWR, Technology (2017) Lithium extraction from Chinese saltlake brines: opportunities, challenges, and future outlook 3:593-597

Sw A, Yw A, Tao CA, Cl A, Yt BJCEJ Porous lithium ion sieves nanofibers: General synthesis strategy and highly selective recovery of lithium from brine water 379 
Tomer VK, Malik R (2019) Hybridized Graphene for Chemical Sensing

Wen Z, Mou Y, Song Z, Xie L, Wang Y, Jing CJPiC (2017) Adsorption Materials for Lithium Ion from Brine Resources and Their Performances

Yang SS, Zhou ML, Wu JQ, Shen JN, Gao CJ Development and Adsorption Properties for a Novel Lithium Ion-Sieve. In: Materials Science Forum, 2016. pp 691-697

Zeng X, Mathews JA, Li JJES, Technology (2018) Urban Mining of E-Waste is Becoming More CostEffective Than Virgin Mining 52:4835-4841

Zhang, Zhang, Fusheng, Yongsheng, Zhongyu, Zheng, Xudong Dual-template docking oriented ionic imprinted bilayer mesoporous films with efficient recovery of neodymium and dysprosium

Zhang LY, Shui Y, Zhao LL, Zhu P, You YHJC (2019) Preparation of Ni-Doped Li2TiO3 Using an Inorganic Precipitation-Peptization Method 9:701

Zhao D, Xue-Min DU, Wang SQ, Guo YF, Deng TLJJoSS, Industry C (2017) Research on Extraction from Salt Lake Brine with High $\mathrm{Mg} / \mathrm{Li}$ Ratio 